\title{
The Development of Microbiology Textbook on the Microorganism Classification Subject for Biology Students of Universitas Negeri Padang Using Science Technology Society (STS) Approach
}

\author{
Putri Islamiah Suci ${ }^{1 *}$ Dwi Hilda Putri ${ }^{1}$ \\ ${ }^{1}$ Biology Department, Math and Natural Science Faculty, Universitas Negeri Padang, Padang, Indonesia \\ *Corresponding author. putriislami1995@gmail.com
}

\begin{abstract}
Initial investigations obtained reference data used by the students so far have been taken from a microbiology book with a long publication year. Based on the results of the questionnaire, the students felt the benefits of studying microbiology in daily life, but the students' references did not support because there was no renewal of science in the references used. This type of research was a development research using the Plomp model. The development phase of the Plomp model consisted of preliminary research, prototype development and assessment. The instruments used were validation assessment sheets, practicality assessment sheets by lecturers and students, and essay questions to assess student knowledge competencies. The results showed that the microbiology textbook on the microorganism classification materials based on Science Technology Society (STS)for students was very valid based on expert judgment in the didactic, construct, and technical fields. The students and lecturers categorized the STS based microbiology textbook on the microorganism classification materials in the very practical category because of their ease of use. The STS based microbiology textbook on the microorganism classification materials was categorized as effective on knowledge competence. Based on the results obtained it was concluded that the microbiology textbook on the STS based microbiology textbook on the microorganism classification materials for Biology Students of Universitas Negeri Padang was declared valid, practical and effective.
\end{abstract}

Keywords: textbook, microbiology,Science Technology Society (STS).

\section{INTRODUCTION}

Education is a very important thing in life aimed at educating people. Higher education is an institution in education that is expected to produce graduates who have scientific academic ability and are able to apply it in their lives. The curriculum in tertiary institutions is regulated and adjusted for each study program by the equalization of the Kerangka Kualifikasi Nasional Indonesia (KKNI).

KKNI according to Presidential Regulation No. 8 of 2012 is a competency qualification framework that can equalize in the field of education. The equalization of the field in the KKNI can be achieved with the achievement of qualified learning for a certain level of education. Learning achievement in tertiary level is equivalent to level 6. In KKNI parameters have been determined learning outcomes where in general the ability to work for level 6 is set to be able to apply, study, design, utilize IPTEKS and solve problems appropriate with their fields [1].

Achievement of the KKNI is needed as a process of developing important components to improve knowledge and skills competence[2]. Improving knowledge competency can be achieved with the learning process. Group based learning has been proven to improve student learning[3] and assignments can also affect student skills[4].

The target of learning achievement in KKNI must go well, one of them is with the lecture process. Education in higher education has compulsory subjects and elective courses. One of the compulsory subjects in the Biology FMIPA UNP department is microbiology. Microbiology is a branch of biology that studies microorganisms. Microorganisms are very small living things that can only be seen with a microscope including bacteria, viruses, and fungi. The field of microbiology studies is one of the fields of study that is important to understand and master because microorganisms have an important role in human life, both beneficial and detrimental.

Based on interviews, it is known that there are still many students who have difficulty understanding the concepts and principles of microbiology. Difficulties of students are seen during the biotechnology lecture process and other optional lectures. To achieve the learning objectives in the 
course, lecturers often have to repeat discussing several microbiology topics so that students can connect with the material to be studied.

The results of the interview also revealed that microbiology lectures used the lecture method and group discussions with students making papers and PPT according to the material. Making papers and PPT is recommended to use references in the form of textbooks and journals, but generally students use more references from the internet (web / blog) that have not been validated. The results of the UNP and UNAND Biology student questionnaire regarding the use of references in microbiology learning, revealed that the references used were not in accordance with the topic and did not include indicators of learning outcomes and the references used did not have any renewed knowledge because they were obtained from books with a long publication year.

Based on a questionnaire given to 72 Biology students, it is known that the topic of the development of microbiology $(51 \%)$, bacteria $(59 \%)$ and viruses $(72 \%)$ is a topic that is difficult for students to master because of the large amount of material and difficult concepts to understand. Maximizing the learning process requires teaching materials that can support students in understanding concepts well, thinking critically and being able to apply them in daily life.

Teaching material that enables students to reach concept understanding well is textbooks. Textbooks have an important role in the learning process. Educators are required to be able to compile textbooks that are interesting, innovative, contextual and in accordance with the needs of students. The textbook used can improve student learning outcomes[5]. Textbooks can also trigger students to improve their intellectual abilities in learning[6]. The use of textbooks can facilitate and facilitate the delivery of material to students [7].

Microbiology textbooks that can provide concept understanding are textbooks using the STS approach. STS aims to improve learning achievement and can broaden students' insights[8]. STS is in line with the theory of cognition that defines learning as knowledge and skills gained from everyday life[9] can be seen from the characteristics of STS with the active involvement of students in obtaining information to solve problems in everyday life[10].

STS textbooks can improve student learning competencies. The use of STS can improve critical thinking skills, the ability to apply concepts in everyday life and higher order thinking skills[11]. Based on the problem, a research was conducted on the development of the STS based microbiology textbook on the microorganism classification materials for Biology students at Universitas Negeri Padang.

\section{METHODS}

This type of research was a Plomp model development research which consisted of preliminary research, prototyping phases, and assessment phases[12]. This research aims at producing products in the form of the STS based microbiology textbook on the microorganism classification materials for UNP biology students. This research was conducted at the Faculty of Mathematics and Natural Sciences (FMIPA) Universitas Negeri Padang (UNP). The data in this research were obtained from the validity test questionnaire, practicality test and effectiveness test. This data was included in the primary data, i.e. data obtained directly from research subjects. The instruments used included: 1) self evaluation sheets, 2) validation questionnaires, 3) one to one evaluation questionnaires, 4) small group evaluation questionnaires, 5) practicality questionnaires and 6) effectiveness.

\subsection{Preliminary Research Phase}

The preliminary research phase aims to find out the problems faced by students in microbiology learning. The activities at this stage were in the form of observation, analytical gathering and defining the problems that occur in the learning process. The preliminary research phase started with analyzing the problems and needs of students, microbiology syllabus analysis, and microbiology text analysis.

\subsection{Development or Prototyping Phase}

This stage began after the initial investigation stage was completed. This stage consisted of microscopes that helped in developing and improving products. This stage consisted of several stages of making a prototype as follows.

a.Development of Prototype I

The results of the prototype design in the preliminary research phase were called prototype I. The initial design was done by researchers based on the results of preliminary research that has been done.

b. Development of Prototype II

Prototype II is the stage of development by conducting a self-evaluation using a checklist. Self-evaluation was by revising the textbook itself that has been designed. The evaluation method itself was carried out aimed at reviewing important components in the microbiology textbook.

c. Development of Prototype III

Prototype III was then validated with expert review and one to one evaluation. Validation with expert review is carried out based on expert judgment (validator) from the didactic, construct, and technical aspects. This evaluation was carried out using an expert validation sheet. Validity data was obtained by analyzing the validation questionnaire that has been filled out by the validator. The analysis was carried out with the following steps.

1) Give a score of answers to each indicator with criteria based on scale 1-4.

2) All items given a score are then tabulated and the percentage is searched using the following formula. 
Validity value $=\frac{\text { item score obtained }}{\text { maximum score }} x 100 \%$

3) Determination of the validity value with the following criteria.

Table 1. Criteria for the Validity of Microbiology Textbooks

\begin{tabular}{ll}
\hline Validity Value (\%) & Category \\
\hline $81-100$ & Very Valid \\
$61-80$ & Valid \\
$41-60$ & Quite Valid \\
$21-40$ & Less Valid \\
$0-20$ & Invalid \\
\hline
\end{tabular}

Modified from Riduwan ${ }^{[13]}$

At the same time one-on-one evaluations were carried out on three biology students using interview guide sheets.

\subsection{Assessment Phase}

\subsubsection{Practicality Instruments}

Field tests or large group trials (field tests) were conducted to see the practicality of microbiology textbook that have been designed. Practicality is the level of practicality of textbooks when used in the learning process. Practicality was carried out by lecturers and students who have used the STS based microbiology textbook that were developed. The research data obtained were analyzed by qualitative and quantitative analysis. The practicality data of the use of microbiology textbook on microorganism classification material was analyzed by percentage (\%), using the following formula.

Practicality value $=\frac{\text { item score obtained }}{\text { maximum score }} x 100 \%$

After the percentage is obtained, grouping is done according to the following criteria.

Table 2. Criteria for the practicality of microbiology textbooks

\begin{tabular}{ll}
\hline Practicality Value (\%) & Category \\
\hline $81-100$ & Very Practicality \\
$61-80$ & Practicality \\
$41-60$ & QuitePracticality \\
$21-40$ & LessPracticality \\
$0-20$ & Inpracticality \\
\hline
\end{tabular}

Modified from Riduwan ${ }^{[13]}$

\subsubsection{Instrument of Effectiveness}

The effectiveness instruments were used to collect effectiveness data using student knowledge competency tests. The effectiveness instrument was used to determine the percentage of students' success after attending lectures using microbiology textbooks on STS based microorganism classification materials. Knowledge competency assessment was done by giving a written test in the form of an essay test used to determine student learning outcomes. The student test results were calculated based on individual completeness and the average grade obtained by students. The criteria used by UNP which stated that they pass if the quality obtained was B- to A. The percentages obtained were grouped according to the following criteria.

Table 3. Completeness Criteria of Student Knowledge Competency

\begin{tabular}{lll}
\hline Value Range & Completeness & Conversion \\
\hline A to B- & Complete & Effective \\
\hline $\mathrm{C}+$ to E & Not Complete & Ineffective \\
\hline
\end{tabular}

Universitas Negeri Padang ${ }^{[14]}$

\section{RESULT AND DISCUSSION}

\subsection{Result}

\subsubsection{Preliminary Research Phase}

The preliminary research phase aims to find out the problems faced by students in microbiology learning. The activities at this stage took the form of observation, questionnaire data collection and defining the problems that occur in the lecture process. The results of research conducted by Suci and Putri[15] revealed that first, microbiology lectures were not yet optimal in terms of learning outcomes not yet achieved. Second, the microbiology textbook used by students was not enough to understand the material and its application in daily life. Third, the microbiology textbook were still unavailable that enhance understanding of concepts and newness of science. Fourth, the presentation of material in the microbiology textbook has not yet integrated STS.

\subsubsection{Development or Prototyping Phase}

This research started from the design and manufacture of microbiology textbook products on the material classification of microorganisms based on STS. The STS steps in the microbiology textbook that were developed were aimed at enabling students to apply the material to their daily lives. Microbiology textbooks are designed 
according to STS stages according to Poedjiadi, introduction: initiation /apperception / exploration, concept development, application of concepts in life, stabilization of concepts, and assessment[8]. Lectures using sciencebased microbiology textbooks of community technology aim to improve knowledge competence, train students' process skills, improve applications in daily life so students find learning useful to themselves, foster creative thinking and train students to solve problems in everyday life[8]. When students are invited to be more active and given issues related to daily life through the learning process, good results are obtained[16]. Learning is the interaction of students with the environment to achieve goals[17]. Learning using skills involves students with problems found in everyday life to make the learning process better[18]. The principles in STS showed personal and social views related to society and problems that occurred in the community[19].

Microbiology textbook on microorganism classification material are made using Microsoft Office Publisher 2007 applications. Components in science technology microbiology textbook based on community technology were cover textbooks, preface, table of contents, list of images, list of tables, concept maps, concept steps of community technology science, bibliography, and author biography. The design results at this stage are called prototype I.

The results of prototype I were followed by selfevaluation. In this activity a review of the important components of the microbiology textbook that has been developed has been made using a checklist. This stage is revised to some writing errors and additions. The results of the revised prototype I are called prototype II.

Prototype II was then carried out by expert review and one to one evaluation. Expert evaluation activities carried out by looking at the validity of microbiology textbooks based on validator assessment which includes three aspects, namely didactic, construct and technical. Based on the assessment given by the validator, it can be seen the validity of the learning modules for each aspect in the very valid category. The module validity results can be seen in Table 4.

Table 4. Results of the analysis of validity of microbiology textbooks

\begin{tabular}{lll}
\hline Assessment Aspects & Value (\%) & Category \\
\hline Didactic & 95.83 & Very valid \\
Construct & 83.33 & Very valid \\
Technical & 90.48 & Very valid \\
Average $\quad$ Validity & 89.88 & Very valid \\
Value & & \\
\hline
\end{tabular}

Furthermore, a onetoone evaluation was conducted to obtain input from the student's perspective on the microbiology textbook developed. One to one evaluations were carried out on 3 students with high, medium and low level academic abilities. The revised results of prototype II are called prototype III.
Prototype III that has been developed was evaluated by a small group to get improvements and an evaluation of the practicality of microbiology textbooks. The number of students in a small group test is six people with academic abilities varying from high, medium, and low. Varied student abilities are intended so that responses and suggestions given by students represent the sample population. The results of the small group evaluation provide information that the microbiology textbooks produced are already in the practical category for use with a percentage of $90.37 \%$. The revised results of prototype III are called prototype IV

\subsubsection{Assessment Phase}

Prototype IV was then subjected to field tests on Biology FMIPA UNP students and two microbiology lecturers. The field test aims to see the practicality of using microbiology textbooks on the STM based microorganism classification material developed. The results of practicality tests by students can be seen in Table 5 and microbiology lecturers in Table 6 .

Tabel 5. Results of the analysis of practicality of microbiology textbooks for student

\begin{tabular}{lll}
\hline $\begin{array}{l}\text { Assessment } \\
\text { Aspects }\end{array}$ & $\begin{array}{l}\text { Value } \\
(\mathbf{\%})\end{array}$ & Category \\
\hline User Convenience & 86.27 & Verypractical \\
Efficiency & 84.73 & Verypractical \\
Benefits & 84.03 & Verypractical \\
Average & 85.01 & Verypractical \\
Practicality Value & & \\
\hline
\end{tabular}

Based on Table 5 it is known that the average practicality assessment by students is $85.01 \%$ with very practical criteria. This shows that STS based microbiology textbooks on microorganism classification materials are practically used by students in the microbiology lecture process.

Table 6. Results of the analysis of practicality of microbiology textbooks for lecture

\begin{tabular}{lll}
\hline Assessment Aspects & $\begin{array}{l}\text { Value } \\
(\boldsymbol{\%})\end{array}$ & Category \\
\hline User Convenience & 90.00 & Verypractical \\
Efficiency & 75.00 & Practical \\
Benefits & 83.33 & Verypractical \\
Average $\quad$ Practicality & 82.78 & Verypractical \\
Value & & \\
\hline
\end{tabular}

Based on Table 6 it is known that the average practicality assessment by microbiology textbook was $82.78 \%$ with very practical criteria. This showed that STS based microbiology textbook on the microorganism classification materials were practically used by lecturers in microbiology lectures. 


\subsubsection{Test the Effectiveness of Knowledge Competence}

Effectiveness test results were used as a guideline in knowing the effectiveness of products developed in the form of microbiology textbooks on STS based microorganism classification materials. Data obtained from written tests in the form of essay questions given to students on midterm exams. The knowledge competency results of the student midterm exams can be seen in Fig 1 ..

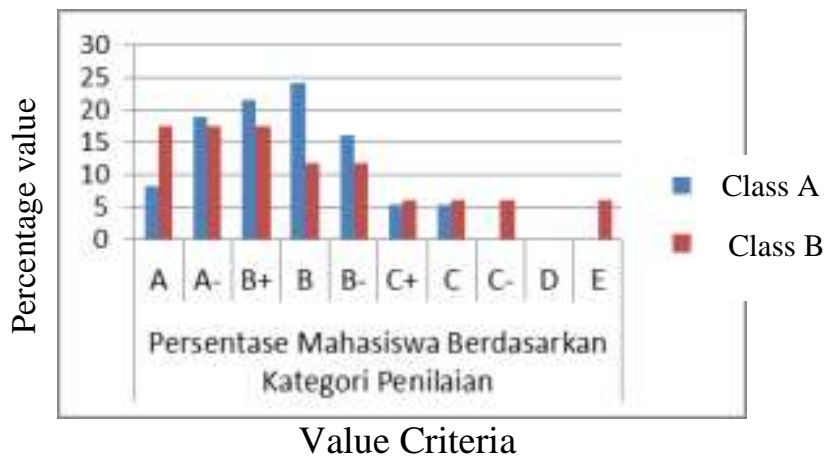

Fig 1. Student knowledge competency results

Based on Table 7 it was known that $82.75 \%$ of students were declared to have passed on the topic of microorganism classification (grades in the categories Bto A) and $17.20 \%$ of students were declared not to pass because they did not meet the completeness criteria. The results of knowledge competency assessment are known that microbiology textbooks on STM-based microorganism classification materials were effective to help students achieve the desired competencies.

\subsection{Discussion}

This research resulted in a product in the form of the STSbased microbiology textbook on the microorganism classification materials. Microbiology textbooks were developed using various letters such as the letters Maiandra GD and Georgia. This was appropriate with the questionnaire for the needs of students who want microbiology textbooks using varying letters. Maiandra GD typeface is formal, simple but easy to read so it is suitable for use in textbooks[20]. Microbiology textbook templates used are dominated by blue and white. The blue color gives an atmosphere of calm, strength and truth[21]. While the white color can provide peace, simplicity and can create new ideas[21].

The validation of microbiology textbooks on STM based microorganism classification materials was carried out by three validators. Data analysis from the validity assessment sheet of this module was reviewed from the aspects of didactics, constructs, and techniques. Sugiyono[22] states that validation is the degree of accuracy between the data that occurs in the research object with the actual data. The results of the module validation data analysis show that the guided inquiry-based learning module has a validity value of $89.88 \%$ with very valid criteria.

The didactic aspects of STS based microbiology textbook were declared valid by the validator with a value of $95.83 \%$ with very valid criteria. From these criteria it can be seen that the microbiology textbook developed has been in accordance with the syllabus and learning outcomes. Validation refers to the accuracy, significance, and usefulness of a research conclusion[23].

The construct aspect was declared valid with a score of $83.33 \%$ with very valid criteria. Based on this it was concluded that STM-based microbiology textbook already use language that is easily understood by students, languages that are in accordance with Indonesian language rules, and have clear sentences.

The technical aspects were declared valid by the validator with a validity value of $90.48 \%$ with very valid criteria. Based on this it was concluded that all components of the technical aspects of the microbiology textbook which included writing, drawing, and graphic were fulfilled properly. Presentation of drawings was needed to support and clarify the material and increase the attractiveness of students[24]. Terms of technical aspects is relating to writing, drawing, and appearance in making microbiology textbooks[25].

The three aspects of evaluating the validation of microbiology textbooks are a unified whole and mutual support to develop good learning modules according to the rules. If a data generated from a product is valid, it can be said that the product developed has provided a description of the development objectives correctly and in accordance with the actual situation[26]. 
One valid one microbiology textbook according to the expert was evaluated. Based on one to one evaluation, it was found that STS based microbiology textbook had good appearance, writing, pictures, and grammar. Then a Small Group Evaluation was carried out through a practicality questionnaire given to six students who aimed to see the practicality of STS based microbiology textbook before conducting a field test. The results of the small group practicality received a very practical category with a value of $90.37 \%$. Textbook said to be practical can be seen from the implementation time which should be short, fast, and precise[27].

Large group practicality test is carried out by students and microbiology lecturers with an average practicality value of $85.01 \%$ by students and $82.78 \%$ by lecturers in very practical categories. Based on the results of the field test the STS based microbiology textbook that was developed provides convenience in terms of its use. This is because the STS based microbiology textbook that was developed was written with writing that is easy to read, a complete description of the material and helps understanding concepts, equipped with clear images, and the renewal of knowledge. STS based microbiology textbooks also have advantages as an important factor in selfidentification as a society[28]

The effectiveness competency test is conducted to determine the results of the use of the STS based

\section{CONCLUSION}

Based on the research that has been carried out, it has been concluded that a microbiology textbook has been produced on the material classification of microorganisms based on science technology society (STS) for Biology students of Universitas Negeri Padang which is valid, practical and effective.

\section{REFERENCES}

[1] Peraturan Presiden Republik Indonesia Nomor 8 tahun 2012 Tentang Kerangka Kulaifikasi Nasional Indonesia.

[2] Loveys, Beth R., Brent N. Kaiser, Glenn McDonald, Olena Kravchuk, Matthew Giliham Steve Tyermen dan Amanda J. Able. 2014. The Development of Student Research Skills in Second Year Plant Biology. International Journal of Innovation in Science and in Athematics Education, 22 (3), 15-25.

[3] Pan, W., dan Allison, J. 2010. Exploring Project Based and Problem Based Learing in Environmental Building Education by in Integrated Critical Thinking. International Journal of Engineering Education, 26 (3), 547553.

[4] Webb, N. M. 2009. The Teacher's Role in Promoting Collaborative Dialogue in The Cllasroom. British Journal of Educational microbiology textbook on the microorganism classification material sin lectures. Lectures require an approach that pays attention to curriculum and assessment[29]. Lectures are adult learning that is monotoritarian and selfdirected[30]. Student learning assessment is an important thing in shaping student motivation and academic performance[31] and looking at student learning outcomes[32]. Lecturers must fully understand the competencies of students[33]. Assessment of knowledge competency tests can be done by means of written tests[34]. The effectiveness test of knowledge competency is assessed through written tests in the form of essays[34]. The use of STS based microbiology textbook had a positive influence on students' knowledge competence. This was because the STS based microbiology textbook contained STS stages so they can hone students' abilities. Learning using STS can provide students the opportunity to increase student activity in lectures[35]. Learning using STS has five stages, namely: apperception, concept development, application of concepts, stabilization of concepts, and evaluation. From the knowledge competency results show that the microbiology textbook on the classification of microorganisms is effectively used by students because it can help students develop thinking skills, problem solving skills, and understand the material well.

Psychology, 79, 1-28.

[5] Ginting, R.U. 2012. Efektivitas Penggunaan Buku ajar dan Belajar Mandiri dalam Rangka Peningkatan Hasil Belajar Termodinamika Dasar. Jurnal Pendidikan Teknologi dan Kejuruan Fakultas Teknik Unimed, 14 (1), 1-7.

[6] Onasanya, S. A dan E. O. Omosewo. 2011. Effect of Improvised and Standard Instructional Materials on Secondary School Students' Academic Performance in Physics in Ilorin Nigeria. Singapore Journal of Scientific Research, 1 (1), 68-76.

[7] Al Azri, Rashid hamed dan Majid Hilal Al Rashdi. 2014. The Effect of Using Authentic Materials in Teaching. International Journal of Scientific \& Technology Research, 3 (10), 249254.

[8] Poedjiadi, Anna. 2005. Sains Teknologi Masyarakat. Bandung: PT Remaja Rosdakarya.

[9] Kok, L., dan Rika, V. 2014. A Science Technology Society Approach To Teacher Education for the Foundation Phase: Students' Empiricist Views. South African Journal of Childhood Education, 4 (1), 95-110.

[10] Akcay, H., dan Yager, R. E. 2010. The Impact of a Science Technology Society Teaching Approach on Student Learning in Five Domains. Journal of Science Education and Technology, 19 (6), 602-611.

[11] Arbi, Y R., Sunarnin R., Putri D H. 2018. Development Module Oriented Science 
Technology Society Indue Science Literacy Assessment for 7th-Grade Junior High School Students in 2nd -Semester. IOP Conf. Series: Materials Science and Engineering 335 (2018) 012089 doi:10.1088/1757-899X/335/1/012089

[12] Plomp, Tjeerd dan Nienke Nieveen. 2013. Educational Design Research. Netherland: Netherlands Institute for Curriculum Development.

[13] Riduwan. 2009. Pengantar Statistika Sosial. Bandung: Alfabeta.

[14] Peraturan Akademik Universitas Negeri Padang 2015.

[15] Suci, Putri Islami dan Dwi Hilda Putri. 2019. Analysis of Needs for the Development of Microbiology Teaching Books Based on Science Technology Society (STM) on Microorganism Classification Materials for Padang University Biology Students. International Journals of Sciences and High Technologies, 15 (1), 86-90.

[16] Kapici, Hasan Ozgur, Hakan Akcay dan Robert E. Yager. 2017.Comparison of ScienceTechnology-Society Approach and Textbook Oriented Instruction on Student's Abilities to Apply Science Concepts. International Journal of Progressive Education, 13 (2), 18-28.

[17] Sudjana, Nana. 2011. Dasar-dasar Proses Belajar Mengajar. Bandung: SinarBaruAlgesindo.

[18] Yalvac, B., Tekkaya, C., Cakiroglu, J., dan Kahyaoglu, E. 2009. Turkish Pre-Service Teacher's Views on Science-Technology-Society Issues. International Journal of Science Education, 29 (3), 331-348.

[19] Moore, V. J., Mc-Cullogh, A. C., dan Chessin, D.A. 2014. Societal Issue in Social Studies and Science Education: Promoting Responsible Citizenship. International Journal of Humanities and Social Science, 4 (10), 69-73.

[20] Pujriyanto. 2005. Desain Grafis Komputer (Teori Grafis Komputer). Yogyakarta: Andi.

[21] Nugroho, Eko. 2008. Pengenalan Teori Warna. Jakarta: Gramedia Pustaka.

[22] Sugiyono. 2012. Metode Penelitian Pendidikan: Pendekatan Kuantitatif, Kualitatif, dan R \& D. Bandung: Alfabeta.

[23] Lufri. 2007. Strategi Pembelajaran, Teori, Praktek dan Penelitian. Padang: UNP Press.

[24] Prastowo, Andi. 2013. Panduan Kreatif Membuat Buku ajar Inovatif: Menciptakan Metode Pembelajaran Yang Menarik Dan Menyenangkan. Jakarta: Kencana.

[25] Trianto. 2009. Mendesain Model Pembelajaran Inovatif: Konsep. Landasan dan Implementasinya pada Kurikulum Tingkat Satuan Pendidikan (KTSP). Jakarta: Kencana Prenada Media Group.

[26] Arikunto. 2013. Dasar-dasar Evaluasi
Pendidikan. Jakarta: Bumi Aksara.

[27] Sukardi. 2011. Evaluasi Pendidikan Prinsip dan Operasionalnya. Jakarta: Bumi Aksara.

[28] Bauchspies, W. K., dan Jennifer C. 2006. Science, Technology, and Society A Sociological Approach. USA: Black Publishing.

[29] Nicholas, Maria. 2015. Student Knowledge: Curriculum, Assessment and Reporting. IBIMA, 14 (3), 1-16.

[30] Uno, H.B. 2008. Model Pembelajaran Menciptakan Proses Belajar Mengajar yang Kreatif dan Efektif. Jakarta: Bumi Aksara.

[31] Brookhat, S. M. 2004. Classroom Assessment: Tensions and Intersections in Theory and Practice. Teachers College Record, 106, 429. 458.

[32] Susilaningsih, E., K. Khotimah dan S. Nurhayati. 2018. Develompment of Performence Assessment Instrument Based Contextual Learning Measuring Students Laboratory Skills. Materials Science and Engineering. 349.

[33] Alkharusi, Hussain, Said Aldhafi, Hilal Alnabhani dan Muna Alkalbani. 2012. Educational Assessment Attitudes, Competence, Knowledge, and Practies: An Exploratury Study of Muscat Teachers in The Sultanate of Oman. Journal of Education and Learning, 1 (2), 217 232.

[34] Yani, Ahmad. 2014. Mindset Kurikulum 2013 Bandung: Alfabeta.

[35] Khan, Natalya N., Sholpan Zh, Kolumbayeva dan Raissa K. Karsybayena. 2016. Evaluation of The Program Effevtiveness of Research Competence Development in Prespective Elementary School Teachers. International Journal of Enviromental \& Science Education, 11 (18), 12299-12316. 